\title{
THE TECHNOLOGICAL ASPECTS OF CREATING A SOLID DOSAGE FORM BASED ON METFORMIN AND BENFOTIAMINE
}

\author{
K.N.Toraev, O.M.Bezchasnyuk, T.V.Shyteyeva \\ National University of Pharmacy \\ Key words: metformin; benfotiamine; antidiabetic drug in capsules
}

\begin{abstract}
Today one of the major problems for the healthcare system of most countries in the world is to optimize pharmacotherapy of diabetes mellitus (DM), which from the category of endemic diseases has turned into a global epidemic in recent decades. In Ukraine there are no drugs that would contain metformin and benfotiamine in their composition, and their combination has not been registered. Creation of a combined drug for the treatment of diabetes mellitus type 2 based on metformin and benfotiamine is promising and will allow not only to control diabetic hyperglycemia qualitatively, but also to prevent development of diabetic polyneuropathy, as well as to reduce side effects of drugs in the combination due to their lower dose. The crystallographic, physicochemical and technological properties of the substances of metformin hydrochloride and benfotiamine, as well as their mixtures have been studied. As a result of the crystallographic, physicochemical and technological studies the composition of the original combined drug in the form of capsules based on metformin and benfotiamine has been developed; it contains metformin $-0.400 \mathrm{~g}$, benfotiamine $-0.020 \mathrm{~g}$, excipients $-0.080 \mathrm{~g}$. The composition of the capsules with metformin and benfotiamine developed has good technological characteristics allowing to choose the direct filling of capsules.
\end{abstract}

Today one of the major problems for the healthcare system of most countries in the world is to optimize pharmacotherapy of diabetes mellitus (DM), which from the category of endemic diseases has turned into a global epidemic in recent decades. Morbidity of diabetes in the world has rapidly increased over the past 50 years and has acquired a threatening nature: currently, approximately 382 million people suffer from DM $[2,4]$, that is $8.3 \%$ of the adult population worldwide, moreover, more than $90 \%$ patients are with diabetes type 2 [17].

The choice of the effective pharmacotherapy of diabetes mellitus requires consideration of the multiple organ disease and involves the use of complex and pathogenetically substantiated therapy, minimization of the risk of hypoglycaemia, cardiovascular pathology, as well development of polyneuropathy, angiopathy and other complications.

Unlike other complications diabetic polyneuropathy (DPN) is often accompanied by a marked pain syndrome, and it leads to a significant deterioration in the quality of life $[3,11]$.

Up to date metformin is the drug with the most proven efficiency and safety for treating DM type $2[6,9$, $20,21,22]$. The content of metformin in the unit of the dosed drug, as a rule, is $500-1000 \mathrm{mg}$. There are proposals to reduce the amount of metformin in the unit of the dosed drug to $400 \mathrm{mg}$ and $250 \mathrm{mg}$ with a daily dose of $1.0-1.5 \mathrm{~g}$ [7, 10, 23, 24, 25].

Benfotiamine is regarded as the drug of the first choice for prevention of neuropathy progression at present from the standpoint of efficiency and safety $[5,14,15]$. Benfotiamine is an effective drug with a broad spectrum of the therapeutic action that can prevent development of diabetic polyneuropathy, retinopathy and nephropathy in the earliest stages, as well as prevent progression of the disease $[1,12,19]$.

Currently, creation of new highly effective hypoglycemic combined drugs is becoming increasingly important and is of practical significance.

In Ukraine there are no drugs that would contain metformin and benfotiamine in their composition, and their combination has not been registered. Creation of a combined drug for the treatment of DM type 2 based on metformin and benfotiamine is promising and will allow not only to control diabetic hyperglycemia qualitatively, but also to prevent development of diabetic polyneuropathy, as well as to reduce side effects of drugs in the combination due to their lower dose.

According to the analysis of literary data and the results of the pharmacological studies conducted the doses of the active substances in the drug have been substantiated; they are $400 \mathrm{mg}$ of metformin and $20 \mathrm{mg}$ of benfotiamine.

The aim of this work is to study the physicochemical and pharmacotechnological parameters of the active substances in order to develop the optimal composition and scientifically based formulation for a combined drug in the form of capsules based on metformin and benfotiamine.

\section{Materials and Methods}

The crystallographic, physicochemical and technological properties of the substances of metformin hydrochloride ("Aarti Drugs Ltd." company, India) and benfotiamine ("Yonezawa Hamari Chemicals Ltd." company, 


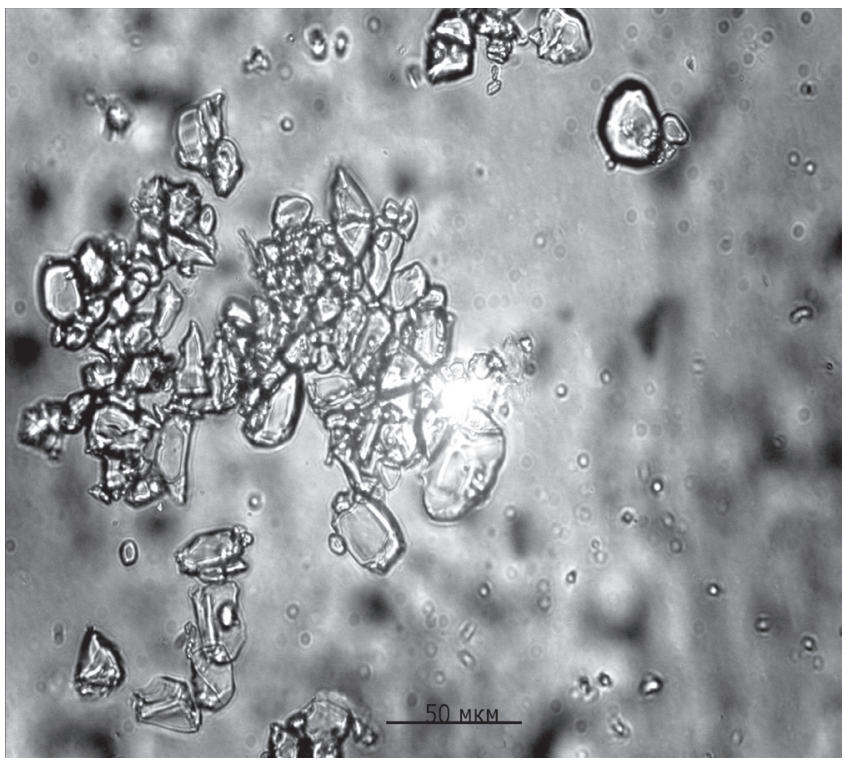

Fig. 1. Crystallography of the metformin powder.

The scale size $-50 \mu \mathrm{m}$.

Japan), the experimental mixtures of these active substances, as well as the encapsulated masses for developing the drug were studied.

The study of the crystallographic characteristics (shape, size of crystals, their surface topography) was carried out by microscopy in accordance with the SPhU I art. 2.9.37 using a microscope with a UNIKO photoadapter (USA) [6].

The physicochemical and technological properties (bulk volume, bulk density, fluidity) of the substances of the active ingredients and experimental mixtures were determined by the standard pharmacopoeial methods $[6,14]$.

\section{Results and Discussion}

Hard gelatin capsules as a dosage form have become increasingly popular with pharmaceutical manufacturers, consumers of medicines and physicians, and it is due to the high accuracy of drug dosing, high bioavailability, guaranteed stability. Medicinal substances are encapsulated in hard capsules in an unchanged form, without being exposed to heat, wet granulation, and pressure. In addition, production of drugs in the form of capsules is more cost-effective as it requires fewer process stages and equipment, energy and labour costs than, for example, in manufacture of tablets.

The possibility of using powders in production is determined by their technological properties, which, to a large extent, depend on their dispersion and the shape of crystals of the substances $[8,16,18]$. Therefore, first of all, the crystallographic parameters of the substances of metformin and benfotiamine were studied.

The shape and size of powder particles for solids depend on the structure of the crystalline lattices and the conditions of the particle growth in the process of crystallization. The presence of substances with the same particle size is the most optimal for obtaining a homogeneous encapsulated mass [14].

Fig. 1 and 2 show crystallographic characteristics of the powders of the active substances under study. The powder of metformin (Fig. 1) is polydisperse, and it is

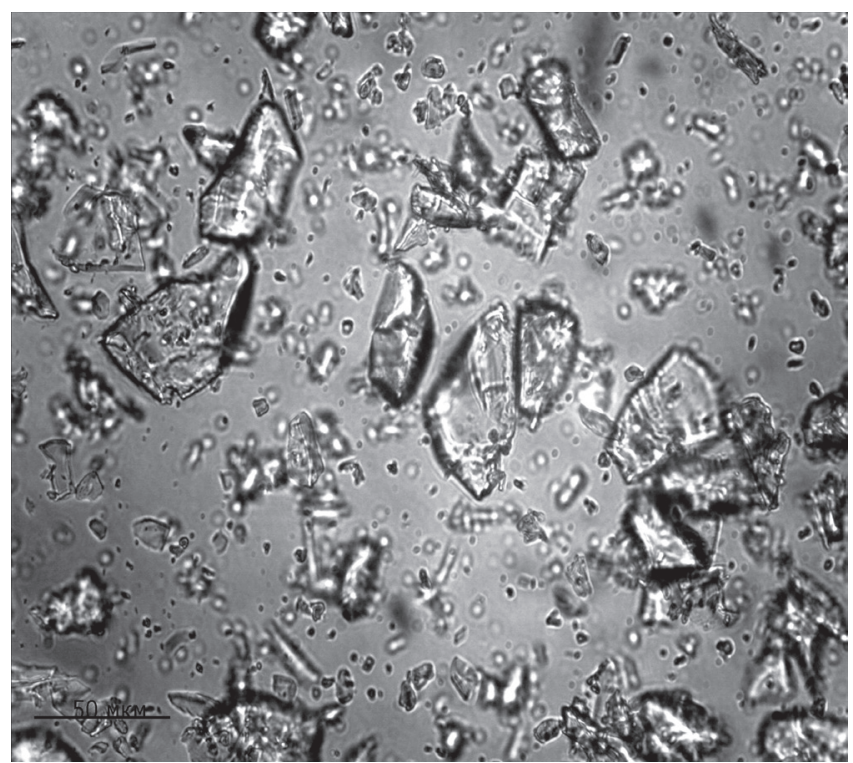

Fig. 2. Crystallography of the benfotiamine powder.

The scale size $-50 \mu \mathrm{m}$

crystals of the orthorhombic form with the different size from $29 \mu \mathrm{m}$ to $238 \mu \mathrm{m}$. Metformin is readily soluble in water and ethanol. It is practically insoluble in acetone and methylene chloride.

The substance of benfotiamine (Fig. 2) is also a polydisperse powder, and it is particles of a crystal-like shape with the different size from $95 \mu \mathrm{m}$ and $339 \mu \mathrm{m}$. There is a tendency to form aggregate complexes. Benfotiamine is slightly soluble in water and methanol and practically insoluble in alcohol and chloroform. It is soluble in sodium hydroxide and sodium hydrocarbonate.

The substances studied have different particle shapes and are characterized by heterogeneity of their size; it is due to reduction of the contact surface between the particles and leads to lower fluidity of the powders. This was confirmed in our further experiments.

The technological characteristics (bulk volume, bulk density, fluidity) of metformin and benfotiamine, as well as their mixtures were studied.

The results of studying the technological characteristics of the substances of metformin and benfotiamine and the experimental mixture of their therapeutic doses are presented in Tab. 1.

The data obtained show that the active substances by their technological parameters have different values: benfotiamine has a good fluidity, and its bulk density is almost twice more than that of metformin. It was also found that metformin and the mixture of the substances of metformin and benfotiamine under research have no fluidity.

The encapsulated dosage form does not require the mandatory introduction of excipients if medicines have satisfactory technological characteristics. They can be used directly to fill gelatin capsules, and it greatly simplifies the manufacturing process. In addition, the fact that the encapsulation systems work on the principle of the complete filling of the capsule volume is also considered. If this condition is not met, it is necessary to introduce excipients that would improve the technological 
The technological properties of the substances studied and their experimental mixture

\begin{tabular}{|l|c|c|c|}
\hline \multicolumn{1}{|c|}{ The technological characteristics } & Metformin hydrochloride & Benfotiamine & $\begin{array}{c}\text { The mixture of metformin } \\
\text { and benfotiamine }(20: 1)\end{array}$ \\
\hline Fluidity, $\mathrm{s} / 100 \mathrm{~g}$ & infinite & 2.57 & infinite \\
\hline Bulk volume $\mathrm{V}_{0}, \mathrm{ml}$ & $102 \pm 0.2$ & $104 \pm 0.2$ & $112 \pm 0.2$ \\
\hline Settled volume $\mathrm{V}_{10}, \mathrm{ml}$ & $96 \pm 0.1$ & $99 \pm 0.2$ & $105 \pm 0.2$ \\
\hline Settled volume $\mathrm{V}_{500}, \mathrm{ml}$ & $62 \pm 0.1$ & $89 \pm 0.1$ & $65 \pm 0.1$ \\
\hline Settled volume $\mathrm{V}_{1250} \mathrm{ml}$ & $62 \pm 0.2$ & $85 \pm 0.2$ & $65 \pm 0.2$ \\
\hline Settling qualities $\mathrm{V}_{10}-\mathrm{V}_{500} \mathrm{ml}$ & $34 \pm 0.5$ & $10 \pm 0.5$ & $40 \pm 0.5$ \\
\hline Bulk density $\mathrm{m} / \mathrm{V}_{0}, \mathrm{~g} / \mathrm{ml}$ & $0.45 \pm 0.02$ & $0.80 \pm 0.01$ & $0.44 \pm 0.02$ \\
\hline Tapped density $\mathrm{m} / \mathrm{V}_{1250} \mathrm{~g} / \mathrm{ml}$ & $0.74 \pm 0.02$ & $0.95 \pm 0.01$ & $0.76 \pm 0.02$ \\
\hline
\end{tabular}

Notes: $n=5 ; P=95 \%$.

The technological characteristics of the encapsulated mass

\begin{tabular}{|l|c|c|c|c|c|}
\hline \multicolumn{1}{|c|}{ Name } & $\begin{array}{c}\text { Bulk volume, } \\
\mathrm{ml}\end{array}$ & $\begin{array}{c}\text { Bulk density, } \\
\mathrm{g} / \mathrm{ml}\end{array}$ & Fluidity, s/100 g & $\begin{array}{c}\text { Angle of repose, } \\
\text { degree }\end{array}$ & $\begin{array}{c}\text { Capsule } \\
\text { disintegration, } \mathrm{min}\end{array}$ \\
\hline $\begin{array}{l}\text { The API mixture: } \\
\text { Metformin 400 mg; } \\
\text { Benfotiamine 20 mg; } \\
\text { MCC; Magnesium stearate }\end{array}$ & $115 \pm 0.02$ & $0.49 \pm 0.01$ & $13.95 \pm 0.01$ & $20 \pm 5$ & $2 \pm 0.5$ \\
\hline $\begin{array}{l}\text { The API mixture: } \\
\text { Metformin 400 mg; } \\
\text { Benfotiamine 20 mg; } \\
\text { Lactose; } \\
\text { Magnesium stearate }\end{array}$ & $118 \pm 0.02$ & $0.79 \pm 0.02$ & $18.95 \pm 0.08$ & $50 \pm 5$ & $12 \pm 0.5$ \\
\hline $\begin{array}{l}\text { The API mixture: } \\
\text { Metformin 400 mg; } \\
\text { Benfotiamine 20 mg; PVP; } \\
\text { Magnesium stearate }\end{array}$ & $120 \pm 0.02$ & $0.59 \pm 0.01$ & $25.95 \pm 0.05$ & $30 \pm 5$ & $15 \pm 0.5$ \\
\hline
\end{tabular}

properties of drugs. Therefore, fillers should be introduced in order to fill the entire volume of the capsule [18].

Microcrystalline cellulose (MCC), lactose, polyvinyl pyrrolidone (PVP) were studied as fillers in order to regulate the technological parameters of the encapsulated mass. To improve the flow properties of the encapsulated mass we used magnesium stearate.

The excipients studied are included in the list of substances approved for use in the pharmaceutical industry and described in the European Pharmacopoeia, SPhU, USP, as well as in "The list of names of excipients included in medicinal products" approved by the Order No.339 of the Ministry of Health of Ukraine dated 19.06.2007 [13].

Based on the therapeutic dose of metformin $(400 \mathrm{mg}$ ) and benfotiamine $(20 \mathrm{mg})$ determined by the pharmacological studies and taking into account the technological aspects for manufacturing capsules the optimal size of capsules was chosen [17].

Calculated on the basis of the bulk density of the substances the volume of the mixture of the active substances in the amount of $420 \mathrm{mg}$ of the drug API was $0.94 \mathrm{~cm}^{3}$. Capsules No.5-No.0 cannot be used for filling since they do not contain the therapeutic dose of the active substances. Capsules No.00 correspond to fill such amount of the mass for encapsulation.

Therefore, as a result of the research conducted it has been confirmed that capsules of size No.00 with the average weight of $0.500 \mathrm{~g}$ are the most rational dosage form for use from the technological point of view; it is due to the different size and shape of particles of the substances studied and the low fluidity.

To provide the complete filling of the volume of the capsule No.00 and to increase fluidity of the glidant there was a need for introducing a filler in the composition of the encapsulated mass. In the composition of the encapsulated mass the mixture of the active substances is $84 \%$. It is allowed to add up to $1 \%$ of the glidant, and therefore, the amount of the filler should be $12-15 \%$.

To develop the drug composition and study the effect of excipients on the technological properties of the encapsulated mass the masses for encapsulation with the excipients selected were prepared. The results of determining the technological characteristics of the encapsulated masses with different excipients are presented in Tab. 2.

The results of the studies have shown that the fluidity of the composition is most significantly affected by 
the presence of microcrystalline cellulose and magnesium stearate. In addition, close values of the bulk volume and bulk density of this mixture predict that it will not be thickened and compressed during storage and transportation.

Therefore, as a result of the crystallographic, physicochemical and technological studies the composition of the original combined drug in the form of capsules based on metformin and benfotiamine has been developed; it contains metformin $-0.400 \mathrm{~g}$, benfotiamine $0.020 \mathrm{~g}$, excipients $-0.080 \mathrm{~g}$. It is in hard shell gelatin capsules No. 00. The average weight of the contents of one filled capsule is $0.500 \mathrm{~g}$.

The composition of the capsules with metformin and benfotiamine developed has good technological characteristics allowing to choose the direct filling of capsules.
When developing the technology the crystalline state of the powders, loss on sifting and the quantitative ratio of the ingredients were considered.

\section{CONCLUSIONS}

1. The crystallographic properties of the substances of metformin and benfotiamine have been studied.

2 . The technological characteristics of the substances of metformin and benfotiamine, the mixtures of their therapeutic doses and masses for encapsulation (bulk volume, bulk density, fluidity, etc.) have been studied.

3 . The optimal composition of the original combined drug in the form of capsules based on metformin and benfotiamine has been determined. It has been found that the use of microcrystalline cellulose as a filler is the most reasonable.

\section{REFERENCES}

1. Верткин А.Л., Городецฺкий В.В. // Фарматека. - 2005. - №10. - C. 1-6.

2. Всемирная организация здравоохранения / Информацчионый сайт по диабету. - http://www.who.int/ diabetes/ru

3. Гурьева И.В., Давыдов О.С. Невропатическая боль при сахарном диабете: причинь, диагностика и обзор международных рекомендаций и алгоритмов лечения // Consilium Medicum. - 2013. - №04. - http:// www.con-med.ru/magazines/consilium_medicum/consilium_medicum-04-013/nevropaticheskaya_bol_pri_ sakharnom_diabete_prichiny_diagnostika_i_obzor_mezhdunarodnykh_rekomendat

4. Гурьева И.В. // Фарматека. Эндокринол. - 2010. - №16(210). - C. 26-30.

5. Державний реєстр лікарських засобів України. - http://www.drlz.kiev.ua

6. Державна фармакопея України / Державне підприємство «Науково-експертний фармакопейний иентр». 1 вид. - Х.: РІРЕГ, 2001. - 556 c.

7. Друк И.В. // Лечашчий врач. - 2011. - №5. - http://www.lvrach.ru /2011/05/15435199

8. Емшанова С.В. // ИД «Медищинский бизнес»-http://www. medbusiness.ru/365.php

9. Зилов А.В., Терехова А.Л. // Лечащчий врач. - 2008. - №3. - http://www.lvrach.ru/2008/03/4906285

10. Компендиум 2014 - лекарственные препараты // On-line. - http://compendium.com.ua

11. Левін І.В., Потолочна М.Д., Гармаш Ю.Ю. // Ендокринол. - 2007. - Т. 7, №12. - С. 26-28.

12. Маркина О.А. // Клин. фармакол. и терапия. - 2003. - №2. - С. 6-9.

13. Перелік допоміжних речовин, дозволених для застосування у виробництві лікарських засобів, які реєструються в Україні: Наказ МОЗ України від 19.06.2007 p. №339. - К., 2007. - 47 с.

14. Промышленная технология лекарств: Учеб. в 2-х т. / В.И. Чуешов, М.Ю. Чернов, Л.Н.Хохлова; под ред. В.И. Чуешова. - Х.: Основа, 1999. - Т. 2. - С. 322.

15. Строков И.А., Строков К.И., Албекова Ж.С. Бенфотиамин в клинической практике // Лечащий врач. 2009. - №9. - http://www.lvrach.ru /2009/11/11175754

16. Строков И.А., Строков К.И., Солуянова Т.В. // Междунар. неврол. журн. - 2010. - №1. - С. 74-81.

17. Тенцева А.И., Ажсихин И.С. Лекарственная форма и терапевтическая эффективность лекарств. - М., Медицина, 1974. - 208 c.

18. Чуешов В.И., Гладух Е.В., Ляпунова О.А. и др. Промышиленная технология лекарств: Электронный учебник // Национальный фармацевтический университет, кафедра заводской технологии лекарств. - Х., 2010. - 558 c. - http://ztl.nuph.edu.ua/html/medication/index.html

19. Ярных Т.Г., Данькевич О.С., Лукиенко О.В. // Провизор. - 1999. - №14. - С. 14-16.

20. Centers for Disease Control and Prevention. National Diabetes Statistics Report: Estimates of Diabetes and Its Burden in the United States, 2014. Atlanta, GA: U.S. Department of Health and Human Services, 2014.

21. International Diabetes Federation (IDF) 20-th World Diabetes Congress: Abstracts 0498 and 0499. Presented October 22, 2009.

22. International Diabetes Federation, Diabetes Atlas - 5-th Ed., Brussels, 2011.

23. Larson N.F. // Diabetes Care. - 2010. - №33. - P. 501-506. 
24. Suzuki K., Yoshioka T., Wakui Y. - 2014. - Vol. 5, №15. - Article ID:48588,8 pages DOI:10.4236/ijcm.2014.515120

25. http://www.ds-pharma.com/news/2010/20100422.html.12

\section{ТЕХНОЛОГІЧНІ АСПЕКТИ ВИРОБНИЦТВА ТВЕРДОЇ ЛІКАРСЬКОЇ ФОРМИ НА ОСНОВІ MЕТФОРМІНУ ТА БЕНФОТІАМІНУ \\ К.Н.Тораєв, О.М.Безчаснюк, Т.В.Шитєєєа \\ Ключові слова: метформін; бенфоотіамін; протидіабетичний препарат у капсулах}

На теперішній час однією з серйозних проблем для системи охорони здоров'я більшості країн світу є оптимізація фрармакотерапії иукрового діабету (ЦД), яка з категорії ендемічного захворювання за останні десятиліття перетворилася на глобальну епідемію. В Україні немає препаратів, які б містили у своєму складі метформін та бенфотіамін, а їх комбінація не зареєстрована. Створення комбінованого лікарського засобу для лікування ЦД другого типу на основі метформіну та бенфотіаміну є перспективним і дозволить не тільки якісно контролювати діабетичну гіперглікемію, але й запобігати розвитку діабетичної поліневропатії, а також дозволить знизити виникнення побічних явищ у комбінації за рахунок більш низького дозування. Були вивчені кристалографрічні, фрізико-хімічні та технологічні показники субстанцій метформіну гідрохлориду і бенфоотіаміну, а також їх суміші. У результаті кристалографрічних, фрізико-хімічних і технологічних досліджень нами було розроблено склад оригінального комбінованого препарату у фоормі капсул на основі метформіну та бенфоотіаміну, який містить метформіну 0,400 г, бенфотіаміну - 0,020 г, допоміжних речовин - 0,080 г. Розроблений склад капсул з метформіном та бенфотіаміном має якісні технологічні характеристики, які дозволяють вибрати пряме наповнення капсул.

\section{ТЕХНОЛОГИЧЕСКИЕ АСПЕКТЫ ПОЛУЧЕНИЯ ТВЕРДОЙ ЛЕКАРСТВЕННОЙ ФОРМЫ НА ОСНОВЕ МЕТФОРМИНА И БЕНФОТИАМИНА \\ К.Н.Тораев, Е.М.Безчаснюк, Т.В.Шитеева \\ Ключевые слова: метформин; бенфротиамин; противодиабетический препарат} в капсулах

На сегодняшний день одной из серьезных проблем для системы здравоохранения большинства стран мира является оптимизация фрармакотерапии сахарного диабета (СД), который из категории эндемического заболевания за последние десятилетия превратился в глобальную эпидемию. В Украине нет препаратов, которые бы содержали в своем составе метфрормин и бенфоотиамин, и комбинация их не зарегистрирована. Создание комбинированного лекарственного средства для лечения СД 2 типа на основе метформина и бенфоотиамина является перспективным и позволяет не только качественно контролировать диабетическую гипергликемию, но и предупреждать развитие диабетической полиневропатии, а также позволяет обеспечить снижение побочных действий препаратов в комбинации за счет их более низкой дозировки. Были изучены кристаллографрические, фризико-химические и технологические свойства субстанций метформина гидрохлорида и бенфоттиамина, а также их смеси. В результате кристаллографических, фризико-химических и технологических исследований нами был разработан состав оригинального комбинированного препарата в фрорме капсул на основе метформина и бенфотиамина, содержащий метформина 0,400 2, бенфотиамина - 0,020 г, вспомогательных веществ - 0,080 г. Разработанный состав капсул с меторормином и бенфотиамином имеет хорошие технологические характеристики, которые позволяют выбрать прямое наполнение капсул. 